\title{
Effectiveness of foliar treatment of intensive varieties of spring barleycorn under the conditions of Middle Volga region
}

\author{
N. V. Sanina ${ }^{1 *}, V . V$. Vukolov $^{1}$, and $V . G$. Kutilkin ${ }^{2}$ \\ ${ }^{1}$ Volga Scientific Research Institute of Selection and Seed-Growing named after P.N. Konstantinov - Branch of the Federal State \\ Budgetary Institution of Science Samara Federal Research Scientific Center of Russian Academy of Sciences, 446442 Kinel, Samara \\ region, Russia \\ ${ }^{2}$ Samara State Agrarian University, 446442 Kinel, Samara region, Russia
}

\begin{abstract}
Experimental studies were conducted in 2015-2017 on Agat and Povolzhsky 22 barleycorn varieties in order to identify the effectiveness of foliar treatments with modern drugs. The treatments increased the yield of varieties to $28 \%$. Grain quality indicators did not change. An individual reaction of barleycorn varieties to yield and grain quality was revealed. During the use of the Biostim Grain drug, Souffler + Intermag complexes of Profi Grain and Mival-Agro + Lignogumat + Zelenit N, the net income reached 3561 rubles / ha, and the profitability was $221 \%$.
\end{abstract}

\section{Introduction}

In order to increase the yield of grain crops and stabilize it over the years, it is necessary to use highly productive varieties with good adaptation to specific weather and climate conditions, to observe the cultivation technology, including the introduction of recommended doses of fertilizers [1-4].

The use of mineral fertilizers increases the yield and improves its quality. At the same time, soil moisture is consumed more economically. The effect of stress decreases, increasing the resistance of plants to drought $[5,6]$.

In Samara region, more than $80 \%$ of soils are classified as medium and low-income in terms of humus content. There is a deficiency of the basic elements of plant nutrition and a lack of active forms of microelements and sulfur [7, 8].

In addition, in the continental climate, there is a decrease in the effectiveness of fertilizers applied to soil [9]. At the same time, fertilizers, as in most regions, are insufficiently introduced, mainly due to their high cost $[1,4,9]$. It is possible to improve plant nutrition using foliar treatments with modern fertilizers.

The varieties adapted to the action of biotic and abiotic stressors of the region with high potential productivity were created at P.N. Konstantinov Volga Research Institute of Selection and Seed Production [10, $11]$.

The studies show that the use of new generation fertilizers on modern varieties of barleycorns allows getting stable grain yields by year [12, 13]. The use of drugs or their complexes, which include organic and mineral substances, macro- and microelements, is of considerable interest.

In this regard, the purpose of the research is to study the individual reaction of intensive Agat and Povolzhsky 22 barleycorn varieties when using foliar treatments with modern drugs, their effect on yield and grain quality, agronomic and economic evaluation of their use under the conditions of the Middle Volga.

\section{Materials and methods}

Experimental studies were conducted during 2015-2017 in the fields of the first selective crop rotation of P.N. Konstantinov Volga Research Institute of Selection and Seed Production.

The studies tested the varieties of intensive barleycorn of Agat and Povolzhsky 22 types zoned in the seventh region of the Russian Federation.

The predecessor of the studied varieties of barleycorn was spring wheat. The seeding rate was 4.5 million germinating grains per 1 ha.

For foliar treatments, the following agents were used: complex mineral fertilizers with microelements (Megamix, Intermag Profi Grain, Zelenite N, Zelenite RK); fertilizers based on humic acids (Lignohumate, Prompter); organic fertilizers (Biostim Growth, Biostim Grain, Bioplant Flora); stimulator Mival-Agro. All the agents are included in the list of the State catalog of pesticides and agrochemicals approved for use in the Russian Federation.

Study variants: 1 . Control; 2) Prompter (0.3 1/ ha) + Intermag of Profi Grain (1 1/ ha); 3) Biostim Growth (1 1 / ha) + Intermag Profi Grain (1 l / ha); 4) Grain biostim (1 l / ha); 5) Mival-Agro (10 g / ha) + Megamix (0.3 1/ ha); 6) Mival-Agro (10 g / ha) + Lignohumate (30 g / ha)

Corresponding author: sanina.natalja@yandex.ru 
+ Green N (0.1 1/ ha); 7) Bioplant Flora (1 1/ ha) + Zelenite N (0.05 1 / ha) + Zelenite PK (0.05 1 / ha).

The allocation of plots is systematic, the repetition is threefold. The accounting area is $9.5-10 \mathrm{~m}^{2}$.

Foliar treatment was carried out in variants 2 and 4 once in the tillering period, in variants $3,5,6$ and 7 twice in tillering and tubing periods.

The soil of the experimental plot is typical lowhumus, low-power, light clay black soil. The humus content is $4.3 \%, \mathrm{P}_{2} \mathrm{O}_{5}-60.5 \mathrm{mg} / \mathrm{kg}, \mathrm{K}_{2} \mathrm{O}-91 \mathrm{mg} / \mathrm{kg}$.

The experiments were carried out according to generally accepted methods. Statistical data processing was carried out by the method of two-way analysis of variance $[14,15]$.

\section{Results}

The hydrothermal conditions of barleycorn vegetation periods developed differently during the years of the experiment: 2015 can be described as dry (hydrothermal index $=0.7$ ), 2016 as extremely dry (hydrothermal index $=0.5$ ), and 2017 as subhumid (hydrothermal index = 1.4), which objectively allows evaluating the studied factors.
At the same time, a dry period was observed in all years of research, which, to varying degrees, influenced the realization of the potential of crop yield. Thus, in 2015 , the drought occurred during the third decade of May - June, that is, from the tillering to the formation period of a grain.

The hydrothermal index of these four weeks was 0.17. In 2016, arid stress was noted from the second decade of June to the second decade of July, during the period of active development of the assimilation apparatus and generative organs of barleycorns.

The hydrothermal index of these three weeks was 0.18. In 2017, drought occurred in the second half of the growing season, from the second decade of July and August. The hydrothermal coefficient of this period was 0.05 .

Barleycorn yields largely depended on June weather conditions. The correlation analysis showed that barley productivity was associated with the meteorological indicators of this month: with average air temperature ( $\mathrm{r}$ $=-0.822-1.000)$ and with moderate and strong degree of precipitation $(\mathrm{r}=0.490-1.000)$, as well as with a hydrothermal index in June (Table 1).

At the same time, the conjugation of characters in most variants of the Povolzhsky 22 variety turned out to be stronger than that of the Agat variety.

Table 1. Main meteorological indicators of June and their relation to the yield of barleycorn grains

\begin{tabular}{|c|l|c|c|c|c|c|}
\hline \multirow{2}{*}{$\begin{array}{c}\text { Calendar } \\
\text { period }\end{array}$} & $\begin{array}{l}\text { Meteorological } \\
\text { indicator }\end{array}$ & \multicolumn{3}{|c|}{ Years } & \multicolumn{2}{c|}{ Correlation index of yield and weather } \\
\cline { 3 - 7 } & Temperature, ${ }^{\circ} \mathrm{C}$ & 23.3 & 19.9 & 16.5 & $-0.822-1.000$ & $-0.894-1.000$ \\
\cline { 2 - 6 } & $\begin{array}{l}\text { Weather } \\
\text { June }\end{array}$ & 0.5 & 12.8 & 129.8 & $0.504-0.993$ & $0.863-1.000$ \\
\cline { 2 - 7 } & $\begin{array}{l}\text { elements, mm } \\
\text { index }\end{array}$ & 0.01 & 0.21 & 2.62 & $0.490-0.991$ & $0.855-1.000$ \\
\hline
\end{tabular}

Taking into account the meteorological indicators of June, the least favorable year was 2015, as evidenced by the lowest barleycorn yield in three years - 2.16-2.62 t / ha. Year of 2016 was less stressful when 2.52-3.30 tons of barley grains from 1 ha were obtained.

The most favorable year was 2017 with the productivity of barley varieties of 2.95-3.64 $\mathrm{t} /$ ha (Table 2).

On average, for three years, the Povolzhsky 22 variety proved to be more productive in control and variants 4, 5 and 6, exceeding the Agat variety in this indicator by $0.07-0.17 \mathrm{t} / \mathrm{ha}$. The Agat showed the highest yield in comparison with the Povolzhsky 22 in variants 2 and 3.

A significant increase in grain yield was $0.18 \mathrm{t} / \mathrm{ha}$ and $0.12 \mathrm{t} / \mathrm{ha}$, respectively. In variant 7 , the average productivity of these varieties was at the same level.

The use of modern drugs in the form of foliar treatments contributed to the increase in crop yield by 0.11-0.72 $\mathrm{t} / \mathrm{ha}$ or 5-28\% and depended on the treatment variant and the reaction of the variety.

The increase of the yield of the Agat variety during foliar treatments was $0.26-0.52 \mathrm{t} /$ ha or $11-20 \%$, which was higher than in the Povolzhsky 22 variety by 0.26 $0.39 \mathrm{t} / \mathrm{ha}$ or $10-15 \%$.
The highest yield increase of the Agat variety compared to the control was in variants 2,3 and $7(0.52 \mathrm{t}$ / ha, $0.47 \mathrm{t} / \mathrm{ha}$ and $0.43 \mathrm{t} / \mathrm{ha}$, respectively), and in the Povolzhsky 22 variety - in variants 4, 6 and $7(0.39 \mathrm{t} /$ ha, $0.37 \mathrm{t} /$ ha and $0.37 \mathrm{t} / \mathrm{ha}$, respectively).

During the use of foliar treatments, it is important to maintain grain quality. The protein content of grain was differentiated by year, varieties and sorts. It is known that under the conditions of drought, more protein accumulates in the grain $[6,11]$.

The studies showed that in the dry year (2015) this indicator was $14.2-15.4 \%$, and in the more favorable 2017 , it was in the range of $10.8-12.3 \%$.

The Agat variety in the control and most variants in terms of the amount of protein in grain was $0.3-0.7 \%$ on average for three years higher than the Volga 22 variety.

The increase in barleycorn yield kept the protein content of grain at the control level, which indicates an adequate and balanced nutrition of plants during foliar treatments.

The use of barleycorn grain for feed purposes involves accounting for protein collection per unit area. On average, over three years the value of this indicator was $327.6-390.2 \mathrm{~kg} / \mathrm{ha}$. In the control and in variants 4, 5 and 7 , protein collection was at the same level. 
Table 2. Yield and grain quality of spring barley varieties depending on the use of complex fertilizers

\begin{tabular}{|c|c|c|c|c|c|c|}
\hline \multirow{2}{*}{ Variant } & \multicolumn{4}{|c|}{ Yield, t/ha } & \multirow{2}{*}{$\begin{array}{c}\text { Fiber content, } \\
\% \\
\end{array}$} & \multirow{2}{*}{$\begin{array}{c}\text { Fiber collection, } \\
\mathrm{kg} / \mathrm{ha}\end{array}$} \\
\hline & 2015 & 2016 & 2017 & Average & & \\
\hline \multicolumn{7}{|c|}{ Agat } \\
\hline 1 & 2.16 & 2.58 & 2.95 & 2.56 & 13.3 & 336.8 \\
\hline 2 & 2.51 & 3.10 & 3.64 & 3.08 & 12.5 & 376.2 \\
\hline 3 & 2.41 & 3.24 & 3.43 & 3.03 & 12.9 & 383.5 \\
\hline 4 & 2.48 & 2.97 & 3.12 & 2.86 & 12.9 & 363.8 \\
\hline 5 & 2.57 & 2.70 & 3.20 & 2.82 & 13.1 & 367.4 \\
\hline 6 & 2.27 & 3.05 & 3.22 & 2.85 & 12.6 & 349.9 \\
\hline 7 & 2.45 & 3.30 & 3.23 & 2.99 & 13.2 & 390.2 \\
\hline \multicolumn{7}{|c|}{ Povolzhsky 22} \\
\hline 1 & 2.30 & 2.52 & 3.09 & 2.64 & 12.6 & 327.6 \\
\hline 2 & 2.62 & 2.67 & 3.41 & 2.90 & 12.4 & 357.2 \\
\hline 3 & 2.36 & 2.96 & 3.39 & 2.90 & 12.6 & 359.8 \\
\hline 4 & 2.47 & 2.89 & 3.72 & 3.03 & 12.5 & 369.9 \\
\hline 5 & 2.51 & 2.75 & 3.60 & 2.95 & 12.6 & 367.9 \\
\hline 6 & 2.62 & 2.82 & 3.60 & 3.01 & 12.4 & 369.2 \\
\hline 7 & 2.74 & 3.00 & 3.29 & 3.01 & 12.6 & 374.7 \\
\hline $\mathrm{LSD}_{05}$ general & 0.12 & 0.16 & 0.16 & 0.19 & 0.65 & 45.2 \\
\hline $\mathrm{LSD}_{05}$ variant & 0.09 & 0.11 & 0.11 & 0.13 & 0.46 & 32.0 \\
\hline $\mathrm{LSD}_{05}$ sort & 0.04 & 0.05 & 0.05 & 0.06 & 0.22 & 17.1 \\
\hline
\end{tabular}

The difference between the varieties for this indicator by $19.0-23.7 \mathrm{~kg} /$ ha was noted in variants 2 and 3 with an excess of the Agat variety, and in variant 6 the Volga 22 variety turned out to be higher.

The technological quality of grain of intensive varieties of barleycorn depended on weather conditions during the growing season and varietal characteristics. The Agat variety formed a larger grain with a mass of 1000 seeds of 48.7-50.4 g than the Povolzhsky 22 (47.4$48.5 \mathrm{~g})$.

By the full weight of the grain, the Povolzhsky 22 variety exceeded the Agat variety by 29-34 g / 1 . Significant changes in the weight of 1000 seeds and the nature of the grain in the variants relative to the control was not observed when exposed to the studied drugs.
The agronomic effectiveness of the complexes of preparations varied by year, variant and variety, ranging from 15 to $1821 \mathrm{~kg}$ of barley grain per $1 \mathrm{~kg}$ of spent preparations. The lowest agronomic effectiveness of the preparations turned out to be in variant 3 . On average, it was $118 \mathrm{~kg}$ for the Agat variety and $2265 \mathrm{~kg}$ of grain for the Povolzhsky variety per $1 \mathrm{~kg}$ of preparations with yield gains of 0.47 and $0.26 \mathrm{t} / \mathrm{ha}$. Payment for one kilogram of the active substance of $168-200 \mathrm{~kg} / \mathrm{kg}$ was noted in the Agat variety in the 7 th variant and in the Povolzhsky 22 variety - in the variants 2 and 7. 300-500 $\mathrm{kg}$ of grain per $1 \mathrm{~kg}$ of the active substance was obtained in variants 4 and 5 in two varieties and in the Agat variety in variant 2 .

Table 3. Indicators of economic efficiency when using complex fertilizers on varieties of spring barleycorn

\begin{tabular}{|c|c|c|c|c|c|c|c|c|c|}
\hline Variant & \multicolumn{2}{|c|}{2} & 3 & \multicolumn{2}{|c|}{4} & 5 & \multicolumn{2}{|c|}{6} & 7 \\
\hline Yield increase, $\mathrm{t} / \mathrm{ha}$ & 0.15 & 0.69 & 0.66 & 0.17 & 0.39 & 0.51 & 0.11 & 0.47 & 0.72 \\
\hline Additional income, rubles/ha & 1125 & 5175 & 4950 & 1275 & 2925 & 3825 & 825 & 3525 & 5400 \\
\hline Total cost of the agents, rubles/ha & \multicolumn{2}{|c|}{279} & 1410 & \multicolumn{2}{|c|}{471} & 434 & \multicolumn{2}{|c|}{270} & 584 \\
\hline Additional costs, rubles/ha & 536 & 1335 & 1291 & 566 & 891 & 1069 & 477 & 1010 & 1694 \\
\hline Total additional costs, rubles/ha & 815 & 1614 & 2701 & 1037 & 1362 & 1503 & 747 & 1280 & 2278 \\
\hline $\begin{array}{l}\text { Share of the agents in total } \\
\text { additional costs, } \%\end{array}$ & 34 & 17 & 52 & 45 & 35 & 29 & 36 & 21 & 26 \\
\hline Conditional net income, rubles/ha & 310 & 3561 & 2249 & 238 & 1563 & 2322 & 78 & 2245 & 3122 \\
\hline $\begin{array}{l}\text { Economic return of additional } \\
\text { costs, rubles/ha }\end{array}$ & 1.38 & 3.21 & 1.83 & 1.23 & 2.15 & 2.55 & 1.1 & 2.75 & 2.37 \\
\hline Profitability, $\%$ & 38 & 221 & 83 & 23 & 115 & 155 & 10 & 175 & 137 \\
\hline
\end{tabular}


The largest payment for one kilogram of active substance was during the use of the complex in variant 5: on average, 1036 and $1321 \mathrm{~kg}$ of grain were obtained with the increase in grain yield of 0.29 and $0.37 \mathrm{t} / \mathrm{ha}$.

The economic analysis of the use of complex fertilizers showed the feasibility of using drugs in foliar treatments. The variants 2,4 and 6 turned out to be the most economically profitable, in which the additional costs associated with the use of fertilizers were repaid annually due to crop yields of $0.15-0.63 \mathrm{t} / \mathrm{ha}$ and the low cost of agents of 270-471 rubles / ha (table 3 ).

The share of agents in these variants did not exceed $45 \%$ of the total amount of additional costs. Net income in this case amounted to 3561 rubles / ha, and profitability reached $221 \%$.

\section{Conclusion}

The studies showed the effectiveness of foliar treatments with the new generation of studied agents on Agat and Povolzhsky 22 varieties. The yield increase from the use of these agents amounted to $0.26-0.52 \mathrm{t} /$ ha or $10-20 \%$, while the grain quality indicators were preserved. The yield increase depended on the individual reaction of the variety and varied by variant and year.

The use of the Bioplant Flora + Zelenit $\mathrm{N}$ and RK complex was the most effective on Agat and Volga 22 varieties with crop yields of 0.43 and $0.37 \mathrm{t} / \mathrm{ha}$.

The use of Souffler + Intermag Profi Grain and Biostim Rost + Intermag Profi Grain complexes increased the productivity of Agat by 0.52 and $0.47 \mathrm{t} /$ ha.

The treatments with the Mival-Agro + Lignogumat + Zelenit $\mathrm{N}$ complex and Biostim Grain agent increased the yield of the Volga 22 variety by 0.37 and $0.39 \mathrm{t} / \mathrm{ha}$.

The most cost-effective was the use of the Biostim Grain, Souffler + Intermag Profi Grain and Mival-Agro + Lignohumat + Zelenite $\mathrm{N}$ complexes: net income amounted to 3561 rubles / ha, and profitability reached $221 \%$.

Thus, the foliar use of most of the studied agents on the Agat and Povolzhsky 22 intensive barley varieties is economically feasible. It allows one to increase grain yield and stabilize its production in the arid zone of the Middle Volga.

\section{References}

1. A. A. Zhuchenko, Adaptive Strategy for the Sustainable Development of Russian Agriculture in the $21^{\text {st }}$ Century. Theory and practice. In two volumes. Vol. 1 (Agrorus, Moscow, 2009-2011)

2. A.V. Rumyantsev, V.V. Glukhovtsev, Scientific support of agricultural production stably productive and high-quality varieties of grain crops Grain Economy of Russia 1, 5-9 (2012)

3. V.V. Glukhovtsev, S.Yu. Tsarevsky, E.V. Stolpivskaya, S.N. Kulyasov, A.S. Tolpekina, The value of spring barleycorn varieties with energysaving cultivation technologies Reports of the Russian Academy of Agricultural Sciences 4, 3-5 (2012)

4. A. V. Alabushev, The state and ways of efficiency of the crop industry. (Kniga, Rostov-on-Don, 2012)

5. V.D. Pannikov, V.G. Mineev, Soil, climate, fertilizer and crop (Agropromizdat, Moscow, 1987)

6. T.M. Yaroshenko, D.Yu. Zhuravlev, N.F. Klimova, Agroecological effectiveness of various doses of mineral fertilizers for grain cultivation in the Middle Volga region Bulletin of the Samara Scientific Center of the Russian Academy of Sciences 20, 351356 (2018)

7. S.V. Obushchenko, V.V. Gnedenko, Analysis of soil fertility in the Samara region Int. J. of Applied and Fundamental Research 4, 90-95 (2015)

8. S.V. Obushchenko, V.V. Gnedenko, The current state of soil fertility in the Samara region in 2016 Int. J. of Applied and Fundamental Research 6, 521525 (2016)

9. V.G. Sychev, S.A. Shafran, The influence of the agrochemical properties of soils on the effectiveness of mineral fertilizers (VNIIA, Moscow, 2012)

10. Catalog of varieties and hybrids of agricultural crops selected by Federal State Budgetary Institution of Volga P.N. Konstantinov Volga Research Institute of Selection and Seed Production (Kinel, 2016)

11. V.V. Glukhovtsev, Selection of spring barley in the Middle Volga (Volga Research Institute of Breeding and Seed Production, Samara, 2005)

12. V.V. Glukhovtsev, N.V. Sanina, A.A. Apalikov, The use of foliar application as elements of the technology of cultivating spring barley in the foreststeppe of the Samara Trans-Volga region Bulletin of the Orenburg State Agrarian University 1, 36-39 (2015)

13. N.V. Sanina, V.V. Glukhovtsev, Features of the use of new generation fertilizers in technologies for the cultivation of spring barley in the arid conditions of the Middle Volga Russian Agricultural Science 3, 36 (2017)

14. B.A. Dospekhov, Methods of field experience (Agropromizdat, Moscow, 1985)

15. V.V. Glukhovtsev, S.N. Zudilin, V.G. Kirichenko, Fundamentals of scientific research in agronomy: a course of lectures (RICA of the State Agricultural Academy, Samara, 2008) 